Hines, M.E. in press. Emissions of sulfur gases from wetlands. In: D.D. Adams, S.P. Seitzinger and P.M. Crill (eds.), Cycling of Reduced Gases in the Hydrosphere.

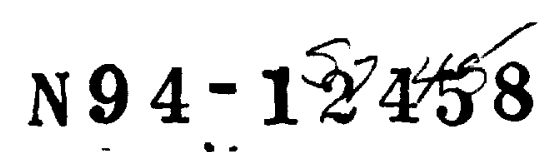

Emissions of Sulfur Gases from Wetlands 181347
$p .21$

\author{
Mark E. Hines
}

Institute for the Study of Earth, Oceans and Space

University of New Hampshire

Durham, NH 03824, USA 


\begin{abstract}
Data on the emissions of sulfur gases from marine and freshwater wetlands are summarized with respect to wetland vegetation type and possible formation mechanisms. The current data base is largest for salt marshes inhabited by Spartina alterniflora. Both dimethyl sulfide (DMS) and hydrogen sulfide $\left(\mathrm{H}_{2} \mathrm{~S}\right)$ dominate emissions from salt marshes, with lesser quantities of methyl mercaptan (MeSH), carbonyl sulfide (COS), carbon disulfide ( $\left.\mathrm{CS}_{2}\right)$ and dimethyl disulfide (DMDS) being emitted. High emission rates of DMS are associated with vegetation that produces the DMS precursor dimethylsulfoniopropionate (DMSP). Although large quantities of $\mathrm{H}_{2} \mathrm{~S}$ are produced in marshes, only a small percentage escapes to the atmosphere. High latitude marshes emit less sulfur gases than temperate ones, but DMS is still the dominate. Mangrove-inhabited wetlands also emit less sulfur than temperate $S$. alterniflora marshes.

Few data are available on sulfur gas emissions from freshwater wetlands. In most instances, sulfur emissions from temperate freshwater sites are low. However, some temperate and subtropical freshwater sites are similar in magnitude to those from marine wetlands which do not contain vegetation that produces DMSP. Emissions are low in Alaskan tundra but may be considerably higher in some bogs and fens.
\end{abstract}

Keywords: Biogenic sulfur gases, wetlands, hydrogen sulfide, dimethyl sulfide, carbonyl sulfide, carbon disulfide, dimethyl disulfide, methyl mercaptan 
Introduction

Gaseous sulfur compounds are intermediate metabolites or end products of biological processes in natural environments. Although the majority of hydrogen sulfide $\left(\mathrm{H}_{2} \mathrm{~S}\right)$ is probably produced through dissimilatory sulfate reduction, other reduced sulfur gases appear to be generated 1) during a variety of anaerobic respiratory or fermentative processes which may be complex; 2) as a cleavage product during decomposition of a biologically-produced compound or; 3) photochemically (Kadota and Ishida 1972; Bremner and Steele 1978; Khalil and Rasmussen 1984; Jørgensen and Okholm-Hansen 1985). It appears that waterlogged areas are conducive to the production and emission of sulfur gases and, when considered on an areal basis, wetlands are strong sources of atmospheric sulfur compounds such as $\mathrm{H}_{2} \mathrm{~S}$, dimethyl sulfide (DMS), methyl mercaptan (MeSH), carbonyl sulfide (COS), carbon disulfide $\left(\mathrm{CS}_{2}\right)$ and dimethyl disulfide (DMDS) (Jørgensen and Sorensen 1985; Steudler and Peterson 1985; Cooper et al. 1987b; Morrison and Hines 1990).

Much of the recent information concerning sulfur gases in wetlands has been derived from studies of rates of gaseous sulfur emissions from these habitats in response to a need to balance the atmospheric sulfur budget and concerns about acid precipitation (Maroulis and Bandy 1977; Möller 1983). However, studies of gas emissions have provided insights into some of the mechanisms of formation and release of sulfur gases. Research on sulfur gas emissions from wetlands, especially those from higher latitudes, and mechanisms which may be responsible for the production of some of these gases will be emphasized in this paper. The reader is referred to recent reviews by Aneja and Cooper (1989) and Giblin and Wieder (in press) who tabulated rates of biogenic sulfur gas emissions from various habitats including salt marshes and freshwater wetlands. 


\section{Marine-Influenced Wetlands}

\section{Temperate Salt Marshes}

Rates of emission of sulfur gases from salt marshes vary diurnally, from one location to the next and from one type of vegetation to another (Table 1). Until the mid1970 's it was thought that salt marshes were a significant global source of gaseous sulfur because they contained large quantities of sulfide (Kellogg et al. 1972; Ivanov 1981). During the last five years it has been demonstrated that the small areal extent of salt marshes precludes them from being an important global source of gaseous sulfur.

The majority of salt marsh work was conducted in stands of Spartina alterniflora which is the predominant grass in many temperate salt marshes. Emissions of DMS usually dominate the flux of sulfur from areas inhabited by this grass (Table 1). Fluxes of $\mathrm{H}_{2} \mathrm{~S}$ can be high as well. The high rates of DMS emissions from S. alterniflora are undoubtedly due to the presence of high concentrations of the DMS precursor dimethylsulphonioproprionate (DMSP) in all parts of the plant (Dacey et al. 1987). This compound is an osmoregulant in certain marine algae and higher plants. Its enzymatic cleavage yields DMS plus acrylic acid (Cantoni and Anderson 1956; Larher et al. 1977; Stewart et al. 1979; Dacey et al. 1987). Although the turnover of only a small portion of the endogenous pool of DMSP would be needed to produce a large DMS flux, recent investigations supported the premise that the bulk of DMSP cleavage to DMS occurs through microbial decomposition of plant tissue or possibly exuded DMSP rather than by the metabolism of S. alterniflora (Kiene, this volume).

It was demonstrated in laboratory studies that the bulk of DMS loss from soils inhabited by S. alterniflora occurs from the emergent portion of the plant and that the sediments act as a sink (Dacey et al. 1987). Field emission studies showed increased DMS fluxes from sites with the most aboveground biomass (Hines et al. 1989). Conversely, de Mello et al. (1987) reported a two-fold difference in DMS emissions from sites that contained essentially equal quantities of aboveground biomass but contained a 
large difference in the amount of belowground biomass. Although roots and rhizomes of S. alterniflora contain large quantities of DMSP (Dacey et al. 1987), concentrations of DMS in marsh sediment pore waters are low ( $\leq 100 \mathrm{nM}$; Howes et al. 1985). Apparently, DMS released from DMSP in marsh soils is utilized rapidly by soil microflora. Methanogenic and sulfate-reducing bacteria have been shown to decompose DMS in marsh soils (Kiene et al. 1986; Kiene 1988; Kiene and Capone 1988).

Only three species of Spartina have been shown to contain high levels of DMSP: $S$. alterniflora, S. anglica (Larher et al. 1977; Dacey et al. 1987) and S. foliosa (J.D.H. Dacey, pers. comm.). Field emission studies by Morrison and Hines (1990) demonstrated rates of DMS flux from S. alterniflora which were 100 -fold faster than emissions from an adjacent stand of Spartina patens, another common marsh grass. Spartina patens does not produce DMSP (Dacey et al. 1987) which underscores the dominant role of DMSP as a precursor of DMS in these environments.

It is beyond the scope of this paper to address the biogeochemistry of $\mathrm{H}_{2} \mathrm{~S}$ in salt marshes. Considerable work has been conducted on sulfate reduction in salt marshes (eg. (Howarth and Teal 1979; Howes et al. 1983; King 1983; Hines et al. 1989). Even though sulfide concentrations can be very high (mM levels) in marsh sediment pore waters (King 1983; Hines et al. 1989), only a minor portion escapes to the atmosphere (Jørgensen and Okholm-Hansen 1985). Emissions of $\mathrm{H}_{2} \mathrm{~S}$ are affected strongly by tidal pumping which can increase flux rates by as much as four orders of magnitude (Jørgensen and OkholmHansen 1985; Cooper et al. 1987a). Emissions of $\mathrm{H}_{2} \mathrm{~S}$ generally increase at night (Hansen et al. 1978; Jørgensen and Okholm-Hansen 1985; Castro and Dierberg 1987). During the day certain anaerobic photosynthetic microorganisms at the sediment surface consume sulfide while other oxygenic microorganisms increase the depth distribution of oxygen which oxidizes sulfide before it escapes. However, Carroll et al. (1986) reported daytime maxima in $\mathrm{H}_{2} \mathrm{~S}$ emissions from a Spartina marsh. The distribution of dissolved sulfide is influenced strongly by iron geochemistry, and it would be expected that 
emissions would be higher in iron-poor soils such as carbonates. Vegetated soils also tend to prevent the release of $\mathrm{H}_{2} \mathrm{~S}$ compared to organic-rich sulfureta-type sediments (Jørgensen and Okholm-Hansen 1985) because marsh plants deliver oxygen to roots which enhances sulfide oxidation. Periodic dessication during neap tides also tends to oxidize the sediments (Howes et al. 1981; Dacey and Howes 1984; Hines et al. 1989) . Sulfureta-type sediments emitted $20-90 \%$ of the sulfide produced from sulfate reduction compared to non-sulfureta sediments which emitted $<0.02 \%$ (Hansen et al. 1978; Jørgensen and Okholm-Hansen 1985).

Emissions of MeSH, $\mathrm{CS}_{2}, \mathrm{COS}$ and DMDS from salt marshes are considerably slower than the fluxes of DMS or $\mathrm{H}_{2} \mathrm{~S}$ (Table 1). Although emissions of MeSH from a S. alterniflora-inhabited area in New Hampshire were less than DMS emissions they also varied in a similar fashion throughout the day (Morrison and Hines 1990). This suggested that MeSH flux was related mechanistically to DMS emissions or that the demethylation of DMS was responsible for the bulk of the MeSH released. The coincidence between MeSH and DMS emissions was reported for other S. alterniflora soils (Goldan et al. 1987), for agricultural plants grown in the laboratory (Fall et al. 1988) and for certain sites in a Danish estuary (Jørgensen and Okholm-Hansen 1985). The similarity between the daily variation in flux of these gases was not noted for sites dominated by S. patens (Morrison and Hines 1990) or Juncus romeriamus (Goldan et al. 1987) and the emission ratio MeSH:DMS was 30-fold higher in S. patens soils compared to sites inhabited by S. alterniflora.

Emissions of COS from salt marshes are also much lower than DMS emissions from S. alterniflora-inhabited sites (Table 1). Laboratory studies revealed that vegetation consumed $\mathrm{COS}$ in the daylight similarly to $\mathrm{CO}_{2}$ (Fall et al. 1988; Goldan et al. 1988). When flux measurements were made using chambers that employed sulfur-free sweep air only an efflux of gaseous sulfur was determined. However, studies using ambient sweep air containing COS (Steudler and Peterson 1985) or sweep air with COS added (Morrison 
and Hines 1990) demonstrated uptake of COS by S. alterniflora. Conversely, light stimulated the emission of $\operatorname{COS}$ from sediment cores devoid of vegetation (Jørgensen and Okholm-Hansen 1985).

Emissions of $\mathrm{CS}_{2}$ and DMDS were detected in many studies of salt marshes (Table 1). Rates of emission of both these compounds were generally very low and DMDS fluxes were usually lower than those for $\mathrm{CS}_{2}$ (Steudler and Peterson 1985; Cooper et al. 1987a; de Mello et al. 1987). The low emission rates and the often inconsistent temporal trends noted for the emissions of these compounds make interpretations of possible production and emission mechanisms difficult.

Subarctic Salt Marsh

Emissions of sulfur gases from a salt marsh on the Alaskan coast in the Bering Sea were much slower than for temperate salt marshes (Table 1) (Hines and Morrison in press). Unlike temperate marshes, subarctic regions are devoid of vegetation throughout the majority of the intertidal zone with various grasses situated near the high tide line. Hines and Morrison (in press) measured sulfur emissions from sites inhabited by various plants and from a bare mud flat. The site exhibiting the highest flux of sulfur contained the sedge Carex subspathacea. This Carex sp. which emits primarily DMS is grazed thoroughly by geese during the summer. Emissions of DMS doubled when geese feces were left within the emission chamber. Although the DMS emissions were low from this site, the ratio of flux to emergent biomass was similar to data for temperate $S$. alterniflora. This similarity suggested that $C$. subspathacea produces a sulfonium compound like DMSP and that emission of DMS from geese feces is analogous to the enhancement of DMS emissions when DMSP-producing marine algae are grazed by zooplankton (Dacey and Wakeham 1986). Supralittoral vegetation (C. ramenskii) at the Alaskan site was orders of magnitude more abundant than $C$. subspathacea yet emitted little to no DMS. 
Subtropical

Emissions of sulfur gases from mangrove-dominated wetlands (Table 2) were reported in three studies (Castro and Dierberg 1987; Cooper et al. 1987b; Hines et al. in prep.). Cooper et al. (1987b) reported data for soils inhabited by black mangroves (Avicennia germinans) where DMS and $\mathrm{H}_{2} \mathrm{~S}$ emissions were similar in magnitude and varied greatly in response to soil temperature. Emissions of $\mathrm{CS}_{2}$ and DMDS were an order of magnitude lower than DMS or $\mathrm{H}_{2} \mathrm{~S}$. The fluxes all of these gases were much lower than fluxes from S. alterniflora in Florida (Cooper et al. 1987a; de Mello et al. 1987). Hines et al. (in prep.) also found that sulfur emissions from black mangrove peatty soils were much lower than those for S. alterniflora soils and that their measurements of mid-day rates were nearly an order of magnitude less than those rates reported by Cooper et al. (1987a).

Emissions from salt-tolerant red mangrove (Rhizophora sp.) were also measured by Hines et al. (in prep.). These were consistently higher at sites that were frequently flooded, well drained at low tide and directly adjacent to open water. Areas with a few $\mathrm{cm}$ of standing water over fine-grained carbonate material had surprisingly low emissions compared to drier well-drained sites. Emissions of DMS were dominant. Fluxes of MeSH and $\mathrm{CS}_{2}$ were often relatively high especially from the well drained areas near open water. Emissions of COS were much higher from the well-drained areas as well. There was no significant increases in fluxes when intact Rhizophora sp. plants were included within the enclosures. Sulfur gas fluxes from all of these marine subtropical sites seem to indicate greater emissions from the soil rather than plants. Castro and Dierberg (1987) reported highly variable $\mathrm{H}_{2} \mathrm{~S}$ fluxes from areas dominated by red mangroves. Emissions of sulfur gases have also been determined by Castro and Dierberg (1987) and Cooper et al. (1987a) for regions inhabited by Distichlis sp. and Juncus sp. (Table 1) and by Cooper et al. (1987a) and Hines et al. (in prep.) for the Batis sp. (saltwort) in Florida (Table 2). Temperature variations strongly affected the measured gas fluxes. 
It appears that emissions of sulfur from subtropical marine wetlands are not as high as those from temperate S. alterniflora soils. The major difference is probably the high flux of DMS from S. alterniflora. Even when the year round growing season in the tropics is taken into consideration, these environments do not seem to be significant global sources of atmospheric sulfur. This is in contrast to the estimates made by Adams et al. (1981b) who reported that emissions of sulfur gases increased exponentially along a north to south gradient. More recent work by Andreae et al. (in press) indicated that tropical soils are not unusually high sources of atmospheric gaseous sulfur. However, they sampled only upland soils. As pointed out by Aneja and Cooper (1989), most of the data reported recently appear to indicate that terrestrial sulfur emission rates are as much as 20 -fold lower than those reported nearly a decade ago (i.e. Adams et al. 1981a,b). Although a portion of this descrepancy is probably due to methodogical improvements and a larger data base, recent data suggested that emissions do not increase exponentially from temperate to the tropical regions.

\section{Freshwater Wetlands}

\section{Temperate to Subtropical}

Few studies have addressed the production and emission of sulfur gases in freshwater environments (Table 3). The majority of emission data for inland sites are from soils. However, some of these studies also measured emissions from wetlands. Adams et al. (1981b) found that sulfur emissions were relatively slow in swamps and several peatty "muck" areas throughout the eastern U.S.A. Aneja et al. (1981) reported that emissions of $\mathrm{H}_{2} \mathrm{~S}$ from a freshwater marsh in North Carolina were relatively high but that fluxes of DMS, COS, $\mathrm{CS}_{2}, \mathrm{MeSH}$ and DMDS were less than their detection limit of $\sim 175 \mathrm{nmol} \mathrm{m}^{-2}$ $\mathrm{hr}^{-1}$. Goldan et al. (1987) found that emissions of $\mathrm{COS}, \mathrm{H}_{2} \mathrm{~S}$ and DMS from decaying cattails were low and 10 to 1000 -fold less than those from a salt marsh site. Although $\mathrm{H}_{2} \mathrm{~S}$ fluxes were similar to those from grasses and clover, COS fluxes from cattails (Typha 
sp.) were $\sim 10$-fold higher and DMS fluxes were $\sim 10$-fold lower than fluxes from grasses and clover.

Emissions of sulfur gases from freshwater subtropical wetlands were measured by Cooper et al. (1987b), Castro and Dierberg (1987) and Hines et al. (in prep.) (Table 3). Emissions from sawgrass (Cladium sp.)-dominated areas were similar in magnitude to emissions from some of the marine areas investigated. In fact, emissions from freshwater sites studied by Hines et al. (in prep.) were similar to those from the wet and peatty mangrove sites sampled within a few days of the freshwater areas. Cooper et al. (1987b) found much higher emissions of sulfur during the hottest times of the year. Unlike the marine sites inhabited by mangroves, fluxes of sulfur gases from various freshwater sites doubled when enclosures were placed over sawgrass and/or Muhlenbergia sp. plants (Hines et al. in prep.). The lower total fluxes and the larger leaf areas of these freshwater habitats may result in an increased importance of direct leaf emission of sulfur from freshwater wetland grasses compared to the marine mangrove sites situated within this same large wetland system in the Everglades. Many types of terrestrial plants have been shown to directly release sulfur gases (Rennenberg 1984, 1989; Fall et al. 1988).

Emissions of sulfur from Everglades freshwater sites were twice as high from locations that had burned five months previously compared to adjacent unburned sites (Hines et al. in prep.). Fires are common in wetlands like the Everglades where they contribute to natural species succession and preservation. The recycling of sulfur through plant organic matter, ash, soil microorganisms and plants may influence the natural emissions of sulfur from these environments, or perhaps the enhanced productivity of newly-growing species accounts of the enhanced fluxes. The aboveground biomass was much smaller at the burned sites but its photosynthetic activity was higher (G.J. Whiting, pers. comm.). 
Higher Latitudes

Wetlands are important features in high latitude terrestrial environments. Bogs, fens and non-forested tundra, which remain wet throughout the warmer months, occupy a large percentage of the terrain. Nriagu et al. (1987) found that DMS, and perhaps $\mathrm{H}_{2} \mathrm{~S}$, concentrations were relatively high in standing waters within bogs in Ontario. His calculated fluxes of DMS were similar in magnitude to average oceanic fluxes (Table 3). On the basis of isotopic data he suggested that some of the sulfur emitted from industrial activity that was deposited in these bogs was biologically transformed into DMS and $\mathrm{H}_{2} \mathrm{~S}$ which was re-emitted to the atmosphere.

Recent data for Alaskan tundra (Hines and Morrison in press) demonstrated that emissions of gaseous sulfur from this environment are very low and similar to rates of sulfur emissions from temperate cattails, native grasses and organic-poor soils (Goldan et al. 1987; Lamb et al. 1987; MacTaggart et al. 1987; Staubes et al. 1989) (Table 3). Using enclosures, emissions from tundra were highest from wet meadows and slough areas which contained grasses and some standing water. Sulfur fluxes were slowest from sites dominated by lichens. Emissions from all sites were dominated by DMS; however, $\mathrm{H}_{2} \mathrm{~S}$ could not be quantified with the techniques used at the tundra sites. Since complete water inundation appeared to enhance emissions from tundra it was postulated that low fluxes of sulfur were due in part to hydrological changes in water levels. Tundra environments also tend to accumulate organic matter that is never completely decomposed. However, this environment receives very little input of sulfur from the atmosphere (Talbot et al. in press), of which approximately $0.5 \%$ is re-emitted as DMS.

Contrary to the Alaskan tundra data, emissions of sulfur gases from bogs and fens in New Hampshire were among the highest ever measured for freshwater environments (Hines unpublished data; Table 3). Emissions of DMS which appeared to originate from below the water table in the New Hampshire fen clearly overwhelmed the other quantified gases. Even though $\mathrm{H}_{2} \mathrm{~S}$ was not determined quantitatively, it was routinely noted. There 
are some indications that sulfur gas emissions are strongly influenced by the position of the water table relative to the surface of the mosses. It appears that DMS is produced under anaerobic conditions in bogs as opposed to its possible aboveground source in salt marshes. The fluxes of sulfur gases from the New Hampshire bogs/fens were greater than the calculated emissions reported from bogs in Ontario (Nriagu et al. 1987) even though atmospheric sulfur deposition is probably substantially higher at the Ontario sites. One reason for this discrepancy may be that the Canadian rate data were derived from measurements of DMS in standing water while those in New Hampshire were measured directly at the vegetated sites. From these studies it is unclear 1) if sulfur emissions are relatively rapid from bogs and fens in general; 2) if this emission is regulated primarily by the amount of atmospheric sulfur deposition and is, thus, only rapid in polluted areas and; 3) how sulfur gases are produced in bog environments. Adams et al. (1981b) reported very low emissions of sulfur gases from a fen in Minnesota. The sulfur budget for a bog in Minnesota was nearly balanced indicating that the the loss of gaseous sulfur had to be small on an annual basis (Urban et al. 1989). In addition, Morgan et al. (this volume) found that the concentrations of sulfur gases in the pore waters of a New Jersey fen were quite low and dominated by $\mathrm{H}_{2} \mathrm{~S}$ and DMS.

\section{Conclusions}

Considerable progress has been made in the last $10-15$ years in the quantification of rates of emissions of sulfur gases from wetland habitats. However, the only habitats that have been characterized fairly well are temperate salt marshes and, even there, data are sparse, especially results from seasonal studies. It appears that earlier studies of the role of terrestrial environments in the global sulfur cylce overestimated their importance by as much as a factor of ten. The low latitudes probably emit much less gaseous sulfur to the atmosphere while the high latitudes may be a larger source of these gases than previously thought. The paucity of data underscores the need to include all of the major habitats when assessing the importance of wetlands as sites for production and recycling of gaseous 
sulfur. In addition, studies are needed which address the mechanisms of production and transformation of sulfur gases within the various terrestrial ecospystems.

\section{Acknowledgments}

I am indebted to many colleagues who have provided stimulating discussions and analytical and field assistence. In particular I would like to thank J. Tugel, M. Morrison, S. Knollmeyer, P. Crill, W. de Mello and P. Goldan. This work was supported by the NASA Biospheric Research Program. 


\section{References}

Adams, D.F., S.O. Farwell, M.R. Pack and E. Robinson. 1981a. Biogenic sulfur gas emissions from soils in eastern and southeastern United States. J. Air Pollut. Control Ass. 3I, 1083-1089.

Adams, D.F., S.O. Farwell, E. Robinson, M.R. Pack and W.L. Bamesberger. 1981b. Biogenic sulfur source strengths. Environ. Sci. Technol. I5, 1493-1498.

Andreae, M.O., H. Berresheim, H. Bingemer, J.D. Jacob, B.L. Lewis, S.-M. Li and R.W. Talbot. in press. The atmospheric sulfur cycle over the Amazon basin. 2. Wet season. J. Geophys. Res.

Aneja, V.P. and W.J. Cooper. 1989. Biogenic sulfur emissions: A review, in Biogenic Sulfur in the Environment, E. S. Saltzman and W. J. Cooper (eds.). American Chemical Society, Washington, DC.

Aneja, V.P., J.H. Overton and A.P. Aneja. 1981. Emission survey of biogenic sulfur flux from terrestrial surfaces. J. Air Pollut. Control Ass. 31, 256-258.

Aneja, V.P., J.H. Overton, L.T. Cupitt, J.L. Durham and W.E. Wilson. 1979a. Direct measurements of emission rates of some atmospheric biogenic sulfur compounds. Tellus 31, 174-178.

Aneja, V.P., J.H. Overton, L.T. Cupitt, J.L. Durham and W.E. Wilson. 1979b. Carbon disulphide and carbonyl sulphide from biogenic sources and their contributions to the global sulphur cycle. Nature 282, 493-496.

Bremner, J.M. and C.G. Steele. 1978. Role of microorganisms in the atmospheric sulfur cycle, in Advances in Microbial Ecology, M. Alexander (ed.). Plenum Press, New York.

Cantoni, G.L. and D.G. Anderson. 1956. Enzymatic cleavage of dimethylpropiothetin by Polysiphonia lanosa. J. Biol. Chem. 222, 171-177.

Carroll, M.A., L.E. Heidt, R.J. Cicerone and R.G. Prinn. 1986. OCS, $\mathrm{H}_{2} \mathrm{~S}$, and $\mathrm{CS}_{2}$ fluxes from a salt water marsh. J. Atmos. Chem. 4, 375-395. 
Castro, M.S. and F.E. Dierberg. 1987. Biogenic hydrogen sulfide emissions from selected Florida wetlands. Water, Air Soil Poll. 33, 1-13.

Cooper, D.J., W.Z. de Mello, W.J. Cooper, R.G. Zika, E.S. Saltzman, J.M. Prospero and D.L. Savoie. 1987a. Short-term variability in biogenic sulphur emissions from a Florida Spartina alterniflora marsh. Atmos. Environ. 21, 7-12.

Cooper, W.J., D.J. Cooper, E.S. Saltzman, W.Z. de Mello, D.L. Savoie, R.G. Zika and J.M. Prospero. 1987b. Emissions of biogenic sulphur compounds from several wetland soils in Florida. Atmos. Environ. 21, 1491-1495.

Dacey, J.W.H. personal communication. Woods Hole Oceanographic Institution, Woods Hole, Massachusetts.

Dacey, J.W.H., G.M. King and S.G. Wakeham. 1987. Factors controlling emission of dimethylsulfide from salt marshes. Nature. 330, 643-645.

Dacey, J.W.H. and S.G. Wakeham. 1986. Oceanic dimethylsulfide: Production during zooplankton grazing phytoplankton. Science. 233, 1314-1316.

Dacey, J.W.H. and B.L. Howes. 1984. Water uptake by roots controls water table movement and sediment oxidation in short Spartina alterniflora marsh. Science. 224, 487-490.

de Mello, W.Z., D.J. Cooper, W.J. Cooper, E.S. Saltzman, R.G. Zika, D.L. Savoie and J.M. Prospero. 1987. Spatial and diel variability in the emissions of some biogenic sulfur compounds from a Florida Spartina alterniflora coastal zone. Atmos. Environ. 21, 987-990.

Fall, R., D.L. Albritton, F.C. Fehsenfeld, W.C. Kuster and P.D. Goldan. 1988. Laboratory studies of some environmental variables controlling sulfur emissions from plants. J. Atmos. Chem. 6, 341-362.

Giblin, A.E. and R.K. Wieder. in press. Sulfur cycling in saline and freshwater wetlands - A review, in Sulfur Cycling in Terrestrial Systems and Wetlands, R. W. Howarth and J. W. B. Stewart (eds.). John Wiley, New York. 
Goldan, P.D., R. Fall, W.C. Kuster and F.C. Fehsenfeld. 1988. The uptake of COS by growing vegetation: A major tropospheric sink. J. Geophys. Res. 93, 14,18614,192 .

Goldan, P.D., W.C. Kuster, D.L. Albritton and F.C. Fehsenfeld. 1987. The measurement of natural sulfur emissions from soils and vegetation: three sites in the eastern United States revisited. J. Atmos. Chem. 5, 439-467.

Hansen, M.H., K. Ingvorsen and B.B. Jørgensen. 1978. Mechanisms of hydrogen sulfide release from coastal marine sediments to the atmosphere. Limnol. Oceanogr. $23,68-76$.

Hines, M.E., P.M. Crill and R. Pellitier-Travis. in preparation. Emissions of biogenic sulfur gases from various marine and freshwater wetland habitats in the Florida Everglades.

Hines, M.E., S.L. Knollmeyer and J.B. Tugel. 1989. Sulfate reduction and other sedimentary biogeochemistry in a northern New England salt marsh. Limnol. Oceanogr. 34, 578-590.

Hines, M.E. and M.C. Morrison. in press. Emissions of biogenic sulfur gases from Alaskan tundra. J. Geophys. Res.

Howarth, R.W. and J.M. Teal. 1979. Sulfate reduction in a New England salt marsh. Limnol. Oceanogr. 24, 999-1013.

Howes, B.L., J.W.H. Dacey and S.G. Wakeham. 1985. Effects of sampling technique on measurements of porewater constituents in salt marsh sediments. Limnol. Oceanogr. 30, 221-227.

Howes, B.L., R.W. Howarth, J.M. Teal and I. Valiela. 1981. Oxidation-reduction potentials in a salt marsh: Spatial patterns and interactions with primary production. Limnol. Oceanogr. 26, 350-360. 
Howes, B.L., J.W.H.Dacey and G.M. King. 1983. Carbon flow through oxygen and sulfate reduction pathways in salt marsh sediments. Limnol. Oceanogr. 29, 10371051.

Ivanov, M.V. 1981. The global biogeochemical sulphur cycle, in Some Perspectives of the Major Biogeochemical Cycles, G. E. Likens (ed.). John Wiley, New York.

Jørgensen, B.B. and B. Okholm-Hansen. 1985. Emissions of biogenic sulfur gases from a Danish estuary. Atmos. Environ. 19, 1737-1749.

Jørgensen, B.B. and J. Sørensen. 1985. Seasonal cycles of $\mathrm{O}_{2}, \mathrm{NO}_{3}$ and $\mathrm{SO}_{4}$ reduction in estuarine sediments: The significance of an $\mathrm{NO}_{3}$ reduction maximum in spring. Mar. Ecol. Prog. Ser. 24, 65-74.

Kadota, H. and Y. Ishida. 1972. Production of volatile sulfur compounds by microorganisms. Rev. Microbiol. 26, 127-138.

Kellogg, W.W., R.D. Cadle, E.R. Allen, A.L. Lazrus and E.A. Martell. 1972. The sulfur cycle. Science. 175, 587-596.

Khalil, M.A.K. and R.A. Rasmussen. 1984. Global sources, lifetimes and mass balances of carbonyl sulfide (OCS) and carbon disulfide $\left(\mathrm{CS}_{2}\right)$ in the Earth's atmosphere. Atmos. Environ. 18, 1805-1813.

Kiene, R.P. 1988. Dimethyl sulfide metabolism in salt marsh sediments. FEMS Microbiol. Ecol. 53, 71-78.

Kiene, R.P. this volume. Microbial cycling of organic sulfur gases in marine and freshwater environments. in Cycling of Reduced Gases in the Hydrosphere, D.D. Adams, S.P. Seitzinger and P.M. Crill (eds.).

Kiene, R.P. and D.G. Capone. 1988. Microbial transformations of methylated sulfur compounds in anoxic salt marsh sediments. Microb. Ecol. 15, 275-291.

Kiene, R.P., R.S. Oremland, A. Catena, L.G. Miller and D.G. Capone. 1986. Metabolism of reduced methylated sulfur compounds in anaerobic sediments and by a pure culture of an estuarine methanogen. Appl. Environ. Microbiol. 52, 1037-1045. 
King, G.M. 1983. Sulfate reduction in Georgia salt marsh soils: An evaluation of pyrite formation by use of ${ }^{35} \mathrm{~S}$ and ${ }^{55} \mathrm{Fe}$ tracers. Limnol. Oceanogr. 28, 987-995.

Lamb, B., H. Westberg, G. Allwine and L. Bamesberger. 1987. Measurement of biogenic sulfur emissions from soils and vegetation: Applications of dynamic enclosure methods with Natusch filter and GC/FPD anlysis. J. Atmos. Chem.5, 469-491.

Larher, F., J. Hamelin and G.P. Stewart. 1977. L'acide dimethyl sulphonium-3propanoique de Spartina anglica. Phytochem. 16, 2019-2020.

MacTaggart, D.L., D.F. Adams and S.O. Farwell. 1987. Measurement of biogenic sulfur emissions from soils and vegetation using dynamic enclosure methods: Total sulfur gas emissions via MFC/FD/FPD determinations. J. Atmos. Chem. 5, 417-437.

Maroulis, P.J. and A.R. Bandy. 1977. Estimates of the contribution of biologically produced dimethyl sulfide to the global sulfur cycle. Science. 196, 647-648.

Möller, D. 1983. Estimation of the global man-made sulphur emission. Atmos. Environ. 18, 19-27.

Morgan, M., M. Diegmann and H. Spratt. this volume. Fate of anthropogenic sulfur in a cedar-dominated wetland. in Cycling of Reduced Gases in the Hydrosphere, D.D. Adams, S.P. Seitzinger and P.M. Crill (eds.).

Morrison, M.C. and M.E. Hines. 1990. The variability of biogenic sulfur flux from a temperate salt marsh on short time and space scales. Atmos. Environ. 24, 17711779 .

Nriagu, J.O., D.A. Holdway and R.D. Coker. 1987. Biogenic sulfur and the acidity of rainfall in remote areas of Canada. Science. 237, 1189-1192.

Rennenberg, H. 1984. The fate of excess sulfur in higher plants. Ann. Rev. Plnat Physiol. 35, 121-153. 

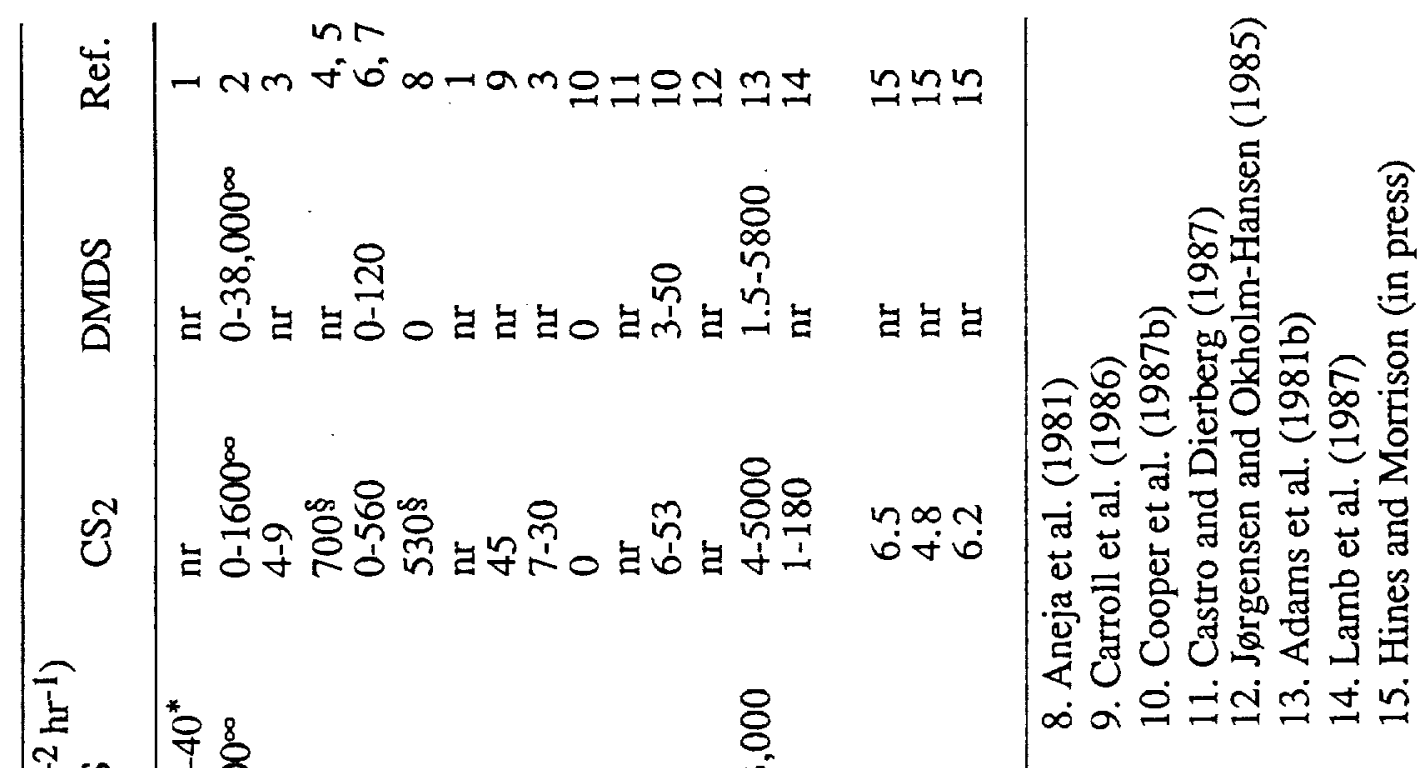

\section{용 용ㅇㅇㅇㅛ}

$\sum_{0}^{\infty}$

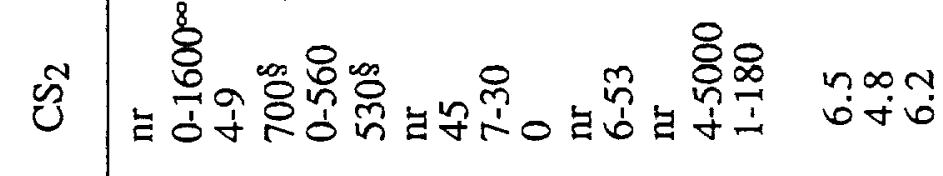

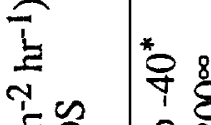

ปู่

8

8

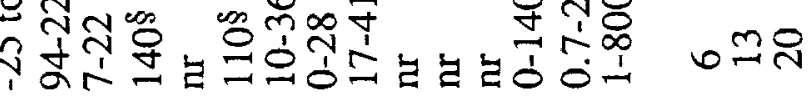

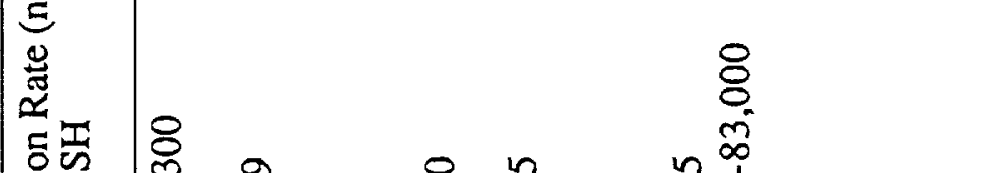

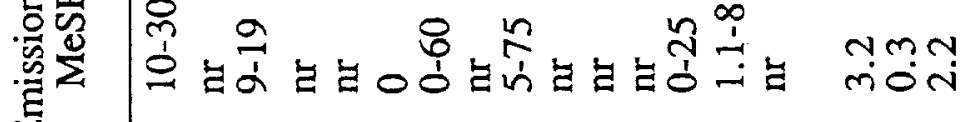
[디

空

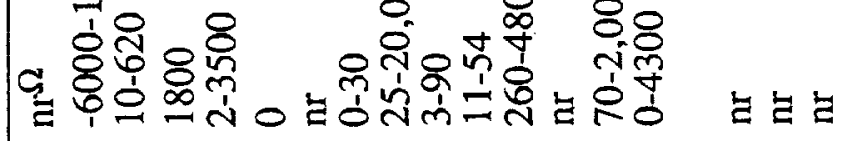<smiles>C=CCCCC</smiles>

通<smiles>CC(C)(C)C</smiles><smiles>CC(C)C</smiles><smiles>C1CCCCCCCCCCCC1</smiles>

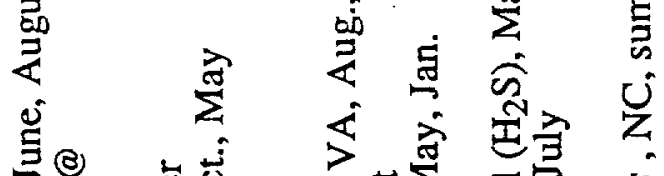

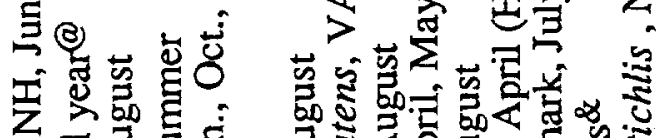

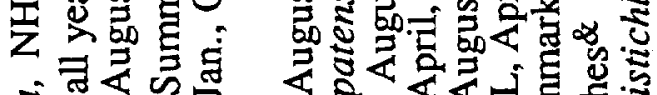

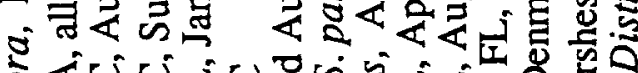

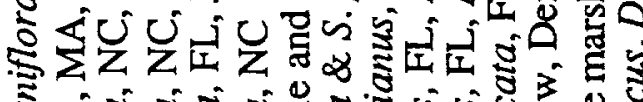

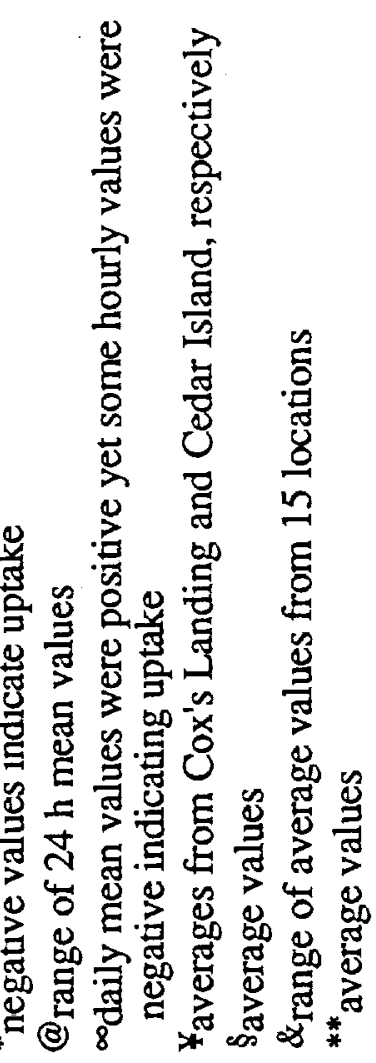




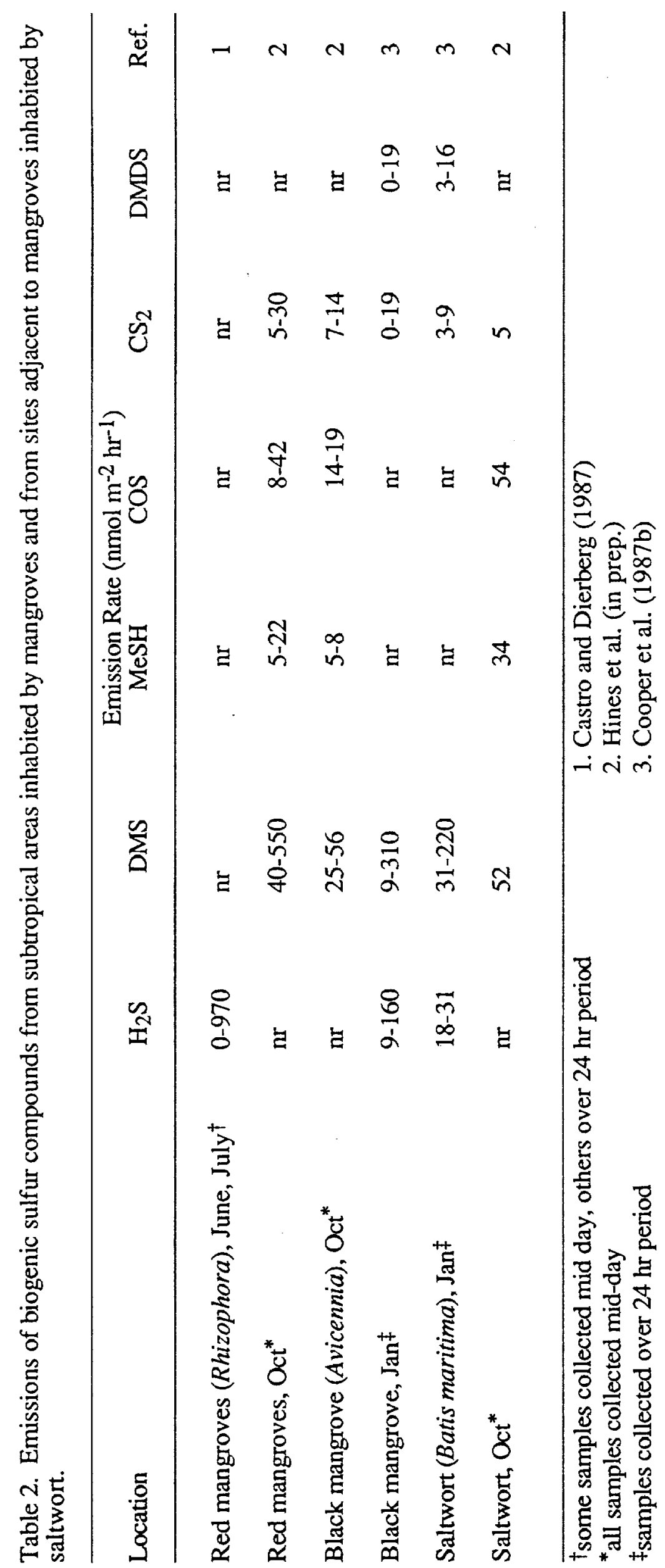




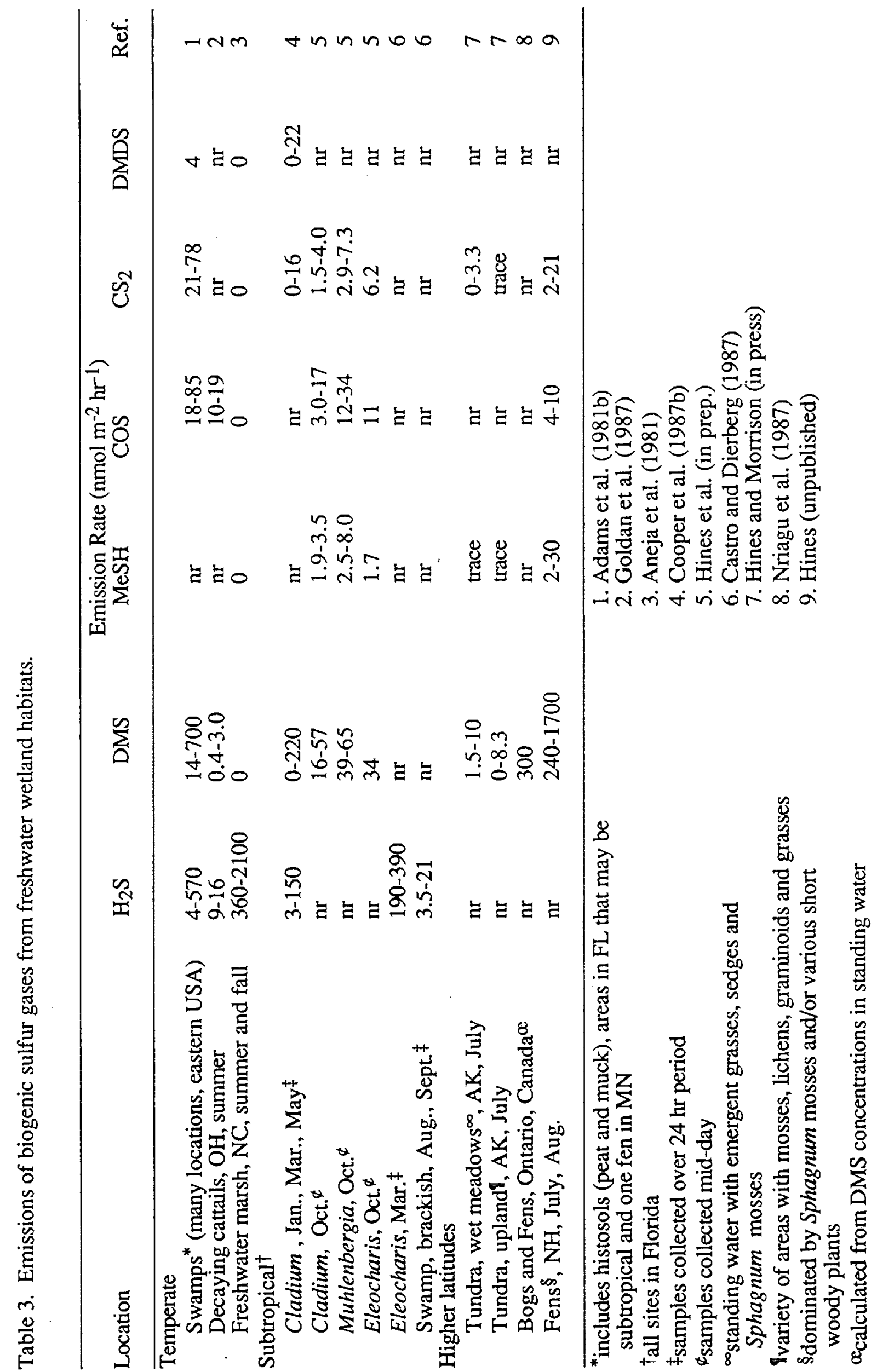

